\title{
Mineralogy of the baotite-bearing Gundrapalli lamproite, Nalgonda district, Telangana, India
}

\author{
Gurmeet Kaur $^{1}$ and Roger H. Mitchell ${ }^{2}$ \\ ${ }^{1}$ Panjab University, Chandigarh, India, gurmeet28374@yahoo.co.in \\ ${ }^{2}$ Lakehead University, Thunder Bay, Ontario, Canada, rmitchel@lakeheadu.ca
}

\section{Introduction}

Ultrapotassic magmatism is quite prevalent in the Eastern Dharwar Complex of south India. Numerous new finds of lamproite dykes from and around the Palaeo-Mesoproterozoic Cuddapah basin gives an opportunity to understand the nature of the subcontinental lithospheric mantle in southern India. We present the mineralogy of a newly discovered lamproite dyke at Gundrapalli village (Nalgonda district) northwest of Cuddapah basin (Figure 1 inset). The lamproite dyke at Gundrapalli village, intruded into the Paleoproterozoic biotite granite unit of Peninsular Gneissic Complex form part of eastern Dharwar Complex. (Figure 1; Kumar et al., 2013, Ahmed et al., 2012).

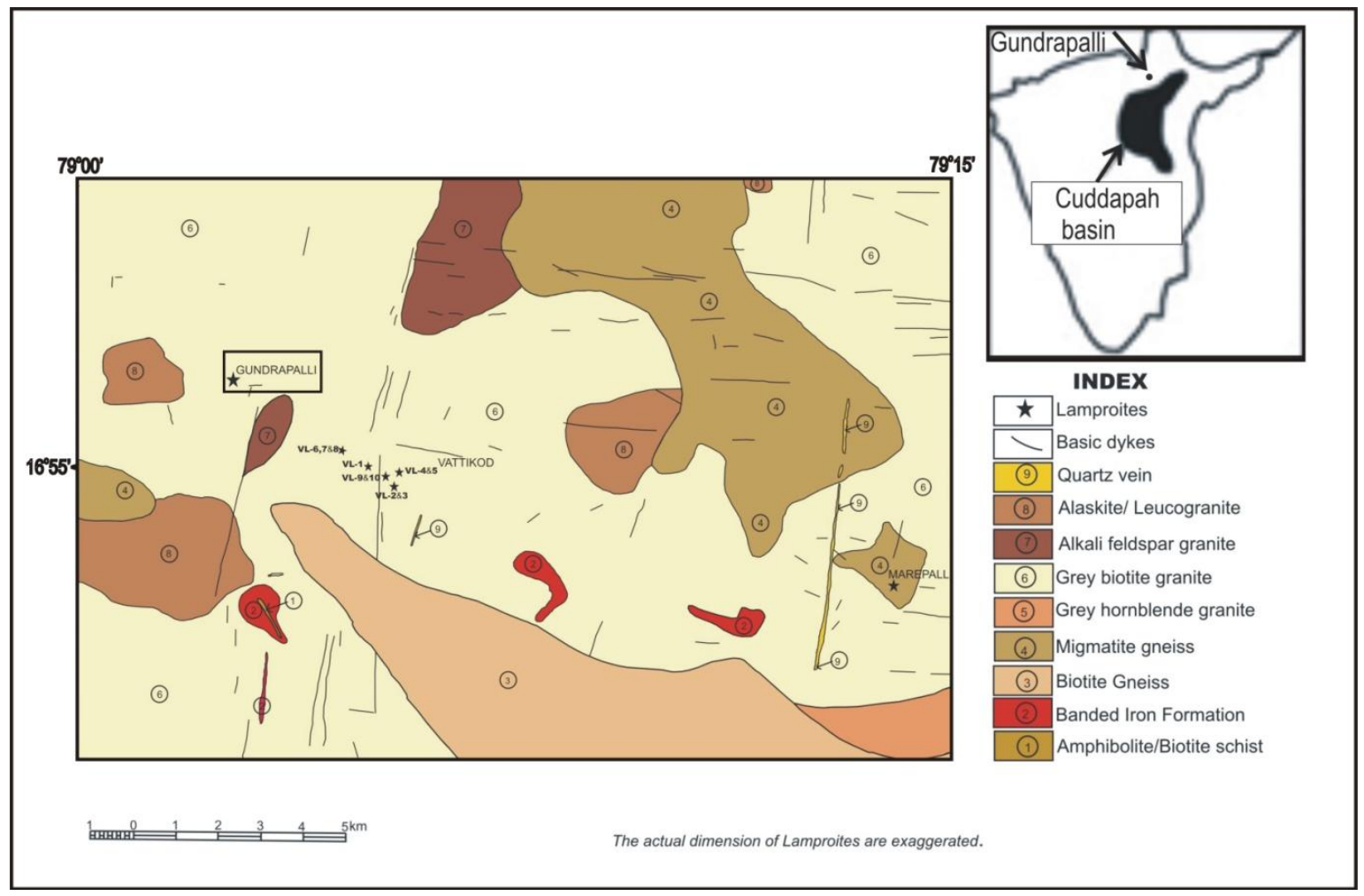

Figure 1: The location of Gundrapalli dyke (northwest of Cuddapah basin; Inset map) and other lamproite dykes of Vattikod in the vicinity of Gundrapalli in Nalgonda district, Telangana, India (after Kumar et al., 2013; Gurmeet Kaur et al., 2016).

\section{Mineralogy of Gundrapalli dyke}

The Gundrapalli dyke consists of a mineral assemblage whose compositions are comparable to those of lamproites in terms of the presence of: phlogopite (Ti-rich, Al-poor); amphiboles (potassicrichterite, potassic-arfvedsonite, magnesio-riebeckite, Ti-rich potassic-magnesio-arfvedsonite, potassic-magnesio-arfvedsonite, katophorite and potassic-ferri-katophorite); Al-poor pyroxene; Kfeldspars (leucite/sanidine), spinel (chromite-magnesiochromite), apatite (fluorine-rich), titanite, rutile, baritocalcite, calcite, ilmenite, hydro-zircon, baotite, strontianite, allanite, quartz and pyrite. The absence of $\mathrm{Ba}-\mathrm{Ti}-\mathrm{Zr}$ minerals such as wadeite, priderite have been compensated for by the 
presence of baotite, rutile, barite, hydrozircons. The presence of secondary phases such as allanite, hydro-zircon, chlorite, quartz and cryptocrystalline $\mathrm{SiO}_{2}$, implies that the dyke has undergone varied degrees of deuteric alteration. We classify the dyke on the basis of its typomorphic major mineralogy as pseudoleucite-phlogopite-amphibole-lamproite.

We report the presence of the rarely occurring mineral, baotite from this lamproite. This is also the first report of mineral baotite from a lamproite from India. Baotite, a Cl-rich barium-titanium-silicate mineral has been earlier reported from a few carbonatites and lamproites, in addition to some alkali granites and pegmatites. Generally, baotites from different rock types have composition varying between the end member $\mathrm{Ba}_{4} \mathrm{Ti}_{8} \mathrm{Si}_{4} \mathrm{O}_{28} \mathrm{Cl}$ and end member $\mathrm{Ba}_{4} \mathrm{Ti}_{2} \mathrm{Fe}^{2+}{ }_{2} \mathrm{Nb}_{4} \mathrm{Si}_{4} \mathrm{O}_{28} \mathrm{Cl}$.

The presence of baotite and fluorine rich apatite is of great importance as a similar mineralogy for lamproites has been reported from the Kvaløya lamproite dyke, intruded into Paleoproterozoic granite, part of the West Troms Basement Complex, on the island Kvaløya, northern Norway. There is striking similarity between the baotite found in Kvaløya and Gundrapalli. Baotites in both rocks form as aggregates with radiating structures instead of well-defined crystals and are closely associated with rutile, amphiboles and (also titanite in case of Gundrapalli) which raise the question of their being of magmatic origin (Figure 2A, B). Another striking similarity between the two dyke rocks is presence of zoned apatites with an early magmatic phase in the core and the REE-rich apatite overgrowths on the cores indicating reactions with the late magmatic fluid.
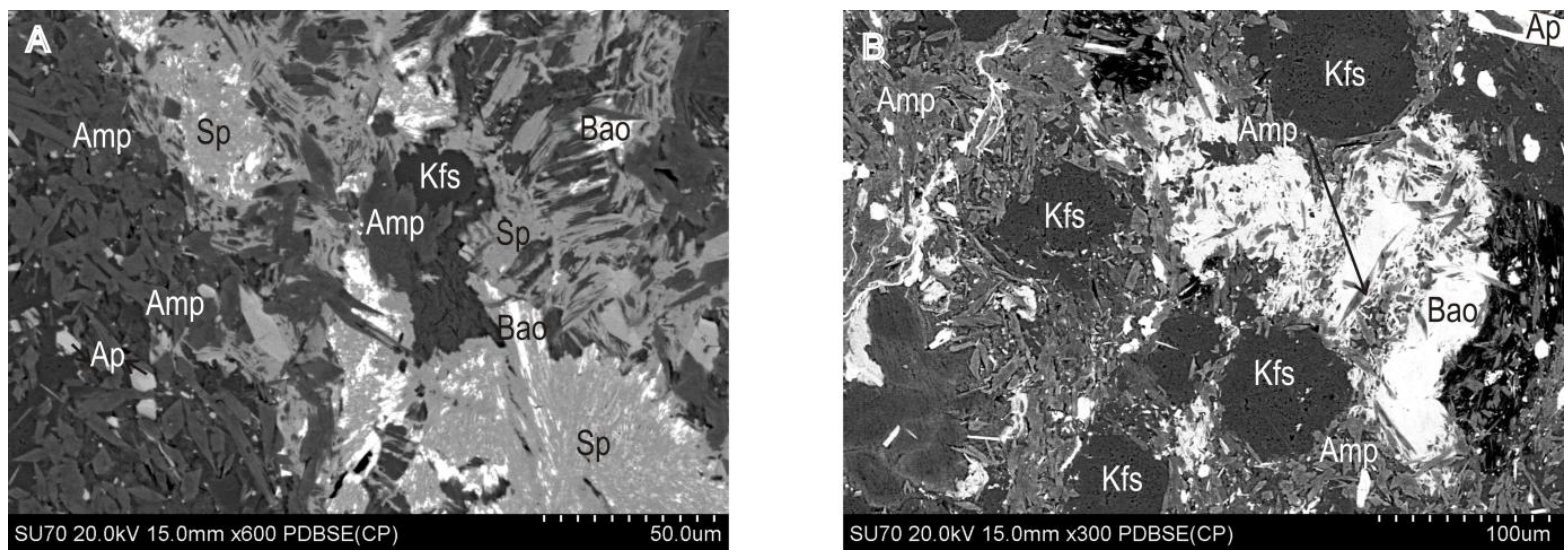

Figure 2A: Baotite in association with titanite (Sp). Also seen are groundmass minerals amphiboles, K-feldspar and apatite (BSE image). Figure 2B: Baotite in association with amphiboles. K-feldspar, amphiboles, apatite and barite form groundmass material (BSE image).

Baotites from both the Norwegian and Indian lamproites are $\mathrm{Nb}$-free types with the composition $\mathrm{Ba}_{4} \mathrm{Ti}_{8} \mathrm{Si}_{4} \mathrm{O}_{28} \mathrm{Cl}$ (Table 1). The high Cl-content of baotite in Gundrapalli, as also in case of Kvaløya, indicates partitioning of $\mathrm{Cl}$ into baotite in the presence of a Cl-bearing F-rich hydrous fluid.

Table 1:

\begin{tabular}{lrrrrrrrr}
\hline Oxides (wt \%) & 1 & 2 & 3 & 4 & 5 & 6 & $7(\mathrm{n}=38)$ & Std. Dev. \\
\hline $\mathrm{SiO}_{2}$ & 15.86 & 15.87 & 15.26 & 15.52 & 15.90 & 15.92 & 15.70 & 0.21 \\
$\mathrm{TiO}_{2}$ & 40.52 & 39.87 & 39.56 & 39.77 & 40.09 & 39.32 & 41.91 & 0.23 \\
$\mathrm{Al}_{2} \mathrm{O}_{3}$ & n.d. & n.d. & n.d. & n.d. & n.d. & n.d. & 0.32 & 0.03 \\
$\mathrm{FeO}^{*}$ & 0.88 & 1.38 & 1.33 & 1.41 & 1.38 & 1.65 & n.d. & \\
$\mathrm{CaO}$ & 2.30 & 2.12 & 3.02 & 0.40 & 2.93 & 1.65 & 0.06 & 0.09 \\
$\mathrm{BaO}$ & 38.34 & 38.11 & 37.89 & 40.71 & 38.71 & 39.40 & 39.20 & 0.24 \\
$\mathrm{SrO}$ & n.d. & n.d. & n.d. & n.d. & n.d. & n.d. & 0.17 & 0.05 \\
$\mathrm{~K} 2 \mathrm{O}$ & n.d. & n.d. & n.d. & n.d. & n.d. & n.d. & 0.16 & 0.07 \\
& & & & $-2-$ & & & &
\end{tabular}




$\begin{array}{lrrrrrrrr}\mathrm{Nb}_{2} \mathrm{O}_{5} & 1.20 & 1.25 & 1.28 & 1.01 & 0.82 & 1.10 & 0.35 & 0.17 \\ \mathrm{Cl} & 2.11 & 2.20 & 2.19 & 2.24 & 1.97 & 2.17 & 2.43 & 0.04 \\ \text { Total } & 101.21 & 100.80 & 100.53 & 101.06 & 101.80 & 101.21 & 100.30 & \\ \mathrm{O}=\mathrm{Cl} & 0.48 & 0.50 & 0.49 & 0.51 & 0.44 & 0.49 & 0.55 & \\ \text { Total } & 100.73 & 100.30 & 100.04 & 100.55 & 101.36 & 100.72 & 99.75 & \end{array}$

Structural formula calculated on the basis of 16 cations

\begin{tabular}{llllllll}
$\mathrm{Si}$ & 3.90 & 3.92 & 3.95 & 3.91 & 3.86 & 3.94 & 3.96 \\
$\mathrm{Ti}$ & 7.49 & 7.41 & 7.24 & 7.54 & 7.32 & 7.33 & 7.94 \\
$\mathrm{Al}$ & 0.00 & 0.00 & 0.00 & 0.00 & 0.00 & 0.00 & 0.10 \\
$\mathrm{Fe}$ & 0.18 & 0.29 & 0.27 & 0.30 & 0.28 & 0.34 & 0.00 \\
$\mathrm{Ca}$ & 0.61 & 0.56 & 0.79 & 0.11 & 0.76 & 0.44 & 0.02 \\
$\mathrm{Ba}$ & 3.69 & 3.69 & 3.61 & 4.02 & 3.68 & 3.83 & 3.87 \\
$\mathrm{Sr}$ & 0.00 & 0.00 & 0.00 & 0.00 & 0.00 & 0.00 & 0.02 \\
$\mathrm{~K}$ & 0.00 & 0.00 & 0.00 & 0.00 & 0.00 & 0.00 & 0.05 \\
$\mathrm{Nb}$ & 0.13 & 0.14 & 0.14 & 0.12 & 0.09 & 0.12 & 0.04 \\
$\mathrm{Cl}$ & 0.88 & 0.92 & 0.90 & 0.96 & 0.81 & 0.91 & 1.04 \\
\hline \multicolumn{7}{c}{ n.d. -not detected; FeO*total Fe expressed as $\mathrm{FeO}$}
\end{tabular}

Table 1 : Representative compositions (wt. \%) of baotites (1-6) from Gundrapalli lamproite and average composition of baotite (7) from the Kvaløya lamproite $(n=38)$. Data for Kvaløya lamproite taken from Kullerud et al., 2012.

\section{Conclusions}

The Gundrapalli dyke, occurs in vicinity of other lamproites within the Vatikod lamproite field (Gurmeet Kaur et al., 2016) and is classified as pseudoleucite-phlogopite-amphibole-lamproite. Baotite has been identified for the first time from an Indian lamproite. The presence of Ti- and $\mathrm{Ba}-$ rich phases such as baotite, rutile, allanite, titanite together with quartz suggest high aSi, aTi, aBa, in equilibrium with a high-F, Cl-bearing hydrous fluids. The lamproite magmas are generally enriched in $\mathrm{F}$ and $\mathrm{Cl}$ and are characteristic of lamproite rocks (Mitchell and Bergman, 1991). The presence of above $\mathrm{F}$ and $\mathrm{Cl}$ phases indicate that the high $\mathrm{F}, \mathrm{Cl}$ fluids were operational during the formation of Gundrapalli lamproite.

\section{References}

Ahmed S, Kumar A (2012) Search for Kimberlite/lamproite in Paluvayi block in Nalgonda district, Andhra Pradesh.Geological Survey of India report on www.portal.gsi.gov.in.

Gurmeet Kaur, Mitchell RH, Ahmed S (2016) Typomorphic mineralogy of the Vattikod lamproites from Mesoproterozoic Ramadugu Lamproite Field, Nalgonda District, Telangana, India: A plausible manifestation of subduction-related alkaline magmatism in the Eastern Ghats Mobile Belt? $35^{\text {th }}$ IGC abstract id 3482 .

Kullerud K, Zozulya D, Ravna E (2012) Formation of baotite-a Cl-rich silicate-together with fluorapatite and F-rich hydrous silicates in the Kvaloya lamproite dyke, North Norway. Mineralogy and Petrology 105: 145-156.

Kumar A, Ahmed S, Priya R, Sridhar M (2013) Discovery of lamproites near Vattikod area, NW margin of the Cuddapah basin, Eastern Dharwar craton, southern India. Journal of the Geological Society of India 82: 307-312.

Mitchell RH, Bergman SC (1991) Petrology of Lamproites. Plenum Press, New York, 447pp. 